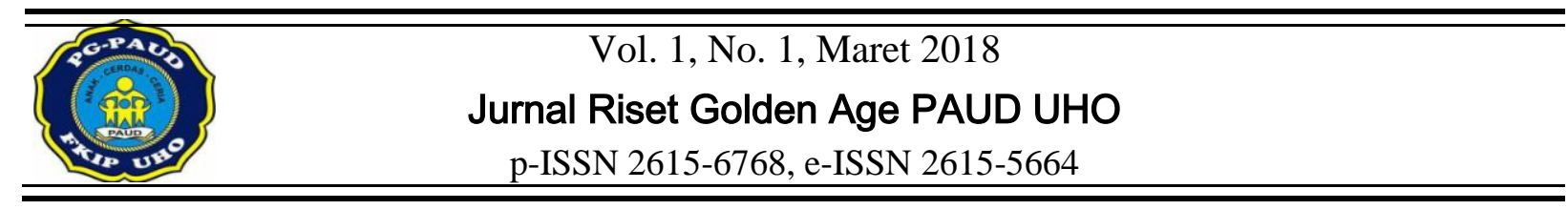

\title{
MENINGKATKAN KEMAMPUAN MENGENAL HURUF HIJAIYAH MELALUI PENERAPAN METODE DRILL PADA KELOMPOK B TK ISLAM KEMARAYA KENDARI
}

\author{
Hasrawati $^{1)}$, Husain Ibrahim ${ }^{2)}$ \\ ${ }^{1}$ Alumni Jurusan PG-PAUD, Universitas Halu Oleo. Jln. H.E.A Mokodompit, Kendari 93232, \\ Indonesia. \\ ${ }^{2}$ Dosen Jurusan PG-PAUD, Universitas Halu Oleo. Jln. H.E.A Mokodompit, Kendari 93232, \\ Indonesia.
}

\begin{abstract}
Abstrak
Tujuan penelitian ini adalah untuk mengetahui apakah penerapan metode drill dapat meningkatkan kemampuan anak dalam mengenal huruf hijaiyah di kelompok B TK Islam Kemaraya Kendari. Subjek dalam penelitian ini adalah guru dan anak yang berjumlah 19 orang. Jenis penelitian ini adalah penelitian tindakan kelas dan dilaksanakan 2 (dua) siklus. Hasil evaluasi kemampuan mengenal huruf hijaiyah anak pada siklus I adalah 9 orang yang terdiri dari 5 orang berada pada kategori BSB (****) dan 4 orang anak dalam kategori BSH $(* * *)$, pada siklus II meningkat menjadi 16 orang yang terdiri dari 7 orang anak barada pada kategori BSB (****) dan 9 orang anak dalam kategori BSH (***). Dengan demikian, maka dapat disimpulkan kemampuan anak mengenal huruf hijaiyah pada Kelompok B Taman Kanak-kanak Islam Kemaraya Kendari dapat ditingkatkan dengan penerapan metode drill.
\end{abstract}

Kata kunci: Pembelajaran, Metode Drill, Huruf Hijaiyah.

\section{INCREASES ABILITY TO KNOW HIJAIYAH FONT PASS THROUGH METHOD IMPLEMENT DRILL AT AGGLOMERATE B TK KEMARAYA KENDARI ISLAM}

\begin{abstract}
Effect this research performing is subject to be know if method implement drill can increase child ability in know hijaiyah's font at agglomerate b TK kemaraya kendari's Islam. Subjek in observational it is learn and group child b kemaraya Islamic Kindergarten that total 19 person, each consisting of 10 males and 9 females. This observational type is observational action braze and be performed 2 (two) cycle. Result evaluates ability know hijaiyah font child on I cycle is $47.3 \%$ or 9 person of 19 childs which consisting of 5 person barada on BSB category(****) and 4 person childs in BSH category(***), on cycle II. worked up as $84.2 \%$ or 16 person of 19 childs which consisting of 7 childs barada on BSB category(****) and 9 childs in BSH category(***). Thus, therefore child ability knows to letter hijaiyah on agglomerate $b$ kemaraya kendari Islamic Kindergarten can be increased by method implement drill.
\end{abstract}

Keywords: Ability, Methods Drill, Letters Hijaiyah

\section{PENDAHULUAN}

Pendidikan adalah suatu kebutuhan yang tidak dapat dipisahkan dari berbagai kebutuhan dalam kehidupan sehari-hari. Hal ini seiring dengan meningkatnya kesadaran masyarakat tentang arti pentingnya pendidikan itu sendiri. Zuhairini (1995 : 42) berpendapat bahwa seluruh proses dalam kehidupan adalah proses pendidikan. Ini dapat diartikan bahwa setiap pengalaman yang didapatkan manusia dalam interaksi dengan orag lain. Lingkungan dan alam dapat diartikan pendidikan dan selanjutnya lingkungan dapat mempengaruhi proses belajar (Darajat, $1986: 34$ ).

Salah satu bentuk pendidikan yaitu Pendidikan Anak Usia Dini (PAUD sebagai pendidikan yang diselenggarakan sebelum jenjang pendidikan dasar, memiliki kelompok sasaran anak usia 0-6 tahun yang sering di sebut 
masa emas perkembangan. Di samping itu, pada usia ini anak-anak masih sangat rentan yang apabila penanganannya tidak tepat justru dapat merugikan anak itu sendiri. Oleh karena itu, penyelenggaraan PAUD harus memperhatikan dan sesuai tahap-tahap perkembangan anak. Program PAUD tidak dimaksudkan untuk mengambil start apa-apa yang seharusnya diperoleh pada jenjang pendidikan dasar, tetapi untuk memberikan fasilitas pendidikan yang sesuai bagi anak, agar anak pada saatnya memiliki kesiapan baik secara fisik, mental, maupun sosial/emosionalnya dalam rangka memasuki pendidikan lebih lanjut.

Bentuk implementasi PAUD salah satunya adalah lembaga Taman Kanak-Kanak yang memberikan layanan pendidikan khususnya bagi anak usia 4 hingga 6 tahun. Pendidikan Anak Usia Dini (PAUD) harus memperhatikan tingkat pencapaian perkembangan yang meliputi lima aspek perkembangan yaitu perkembangan nilai-nilai agama dan moral, motorik, kognitif, bahasa dan sosial emosional. Masing-masing lembaga dapat mengembangkannya sesuai dengan kondisi di lembaga tersebut.

Salah satu aspek yang paling penting untuk dikembangkan pada lembaga PAUD yaitu kemampuan agamanya dalam hal ini kemampuan mengenal huruf hijaiyah. Mengenal kan huruf untuk pendidikan anak usia dini, yaitu anak belajar mengenali huruf dan bunyinya dari konteksnya bahasa yang digunakan. Anak diarahkan untuk mengidentifikasi bentuk huruf dan bunyinya. Jadi anak belajar dari konsep menyeluruh menuju ke konsep yang khusus Susanto (2011: 86). Dalam hal ini konsep menyeluruh yang dikenalkan kepada anak adalah huruf-huruf hijaiyah yang berjumlah 28 huruf, sementara konsep khusus yang dikenalkan adalah bentuk-bentuk huruf dan bunyinya.

Sugiyanto (1996: 72) menyatakan bahwa dalam metode drill siswa melakukan gerakangerakan sesuai dengan apa yang diinstruksikan guru dan melakukan secara berulang-ulang. Pengulangan gerakan ini dimaksudkan agar terjadi otomasisi gerakan

\section{METODE}

Prosedur pelaksanaan dalam penelitian ini terdiri dari dua siklus dan masing-masing siklus terdiri atas empat kali pertemuan. Adapun desain penelitian yang digunakan adalah model yang dikemukakan oleh Kemmis dan Taggart yang dikutip dalam Anonim (2014: 212) bahwa dalam penelitian tindakan kelas ada empat tahapan yang dilalui yaitu sebagai berikut. Pertama, perencanaan: metode ini mencakup pembuatan skenario pembelajaran berupa Rencana Kegiatan Harian (RKH) untuk siklus I pada pertemuan I, pertemuan II, pertemuan III dan pertemuan IV yang mengacu pada pembelajaran peningkatan kemampuan mengenal huruf hijaiyah dengan menggunakan metode drill, menyiapkan media pembelajaran berupa gambar huruf hijaiyah, Membuat lembar observasi aktivitas guru dan anak sebagai acuan untuk melihat tentang keterlaksanaan proses pembelajaran sesuai dengan yang direncanakan. Menyediakan alat evaluasi untuk melihat peningkatan kemampuan pengenalan huruf hijaiyahdengan menggunakan metode drill.

Kedua, pelaksanaan: pada tahap ini penelitian meliputi pelaksanaan tindakan yang dilakukan oleh peneliti/guru sedangkan guru Kelompok B (kolaborator) bertindak sebagai pengamat (observer). Adapun pelaksanaan tindakan: guru memberikan penjelasan bagaimana penggunaan metode drill, implikasi penjelasan dari guru ditindak lanjuti oleh anak didik dengan melakukan kegiatan pembelajaran menggunakan gambar berupa tulisan huruf hijaiyah, Posisi anak didik diatur dengan rapi di dalam kelas agar bisa mengamati dan mengikuti kegiatan pembelajaran dengan baik, setelah posisi anak diatur sesuai dengan yang diharapkan, peneliti memulai kegiatan pembelajaran dengan menggunakan media.

Ketiga, pengamatan/observasi: kegiatan observasi dilakukan setiap kali pertemuan selama pelaksanaan tindakan dalam proses pembelajaran dengan menggunakan lembar observasi yang telah disiapkan. Pada tahap ini dilaksanakan pengamatan secara seksama mengenai aktivitas anak didik selama mengikuti proses pembelajaran membaca huruf hijaiyah dengan menerapkan metode drill. Keempat, refleksi: hasil refleksi digunakan untuk menetapkan langkah-langkah lebih lanjut pada siklus berikutnya, keunggulan dipertahankan dan kelemahan-kelemahan yang terjadi dapat diperbaiki pada siklus berikutnya.

Tiap siklus dijalankan sesuai dengan perubahan yang diinginkan seperti yang telah disusun dalam faktor yang ingin diselidiki. Untuk mengetahui peningkatan yang ada pada anak didik terhadap kemampuan mengenal huruf hijaiyah. 


\section{HASIL DAN PEMBAHASAN}

TK Islam Kemaraya Kendari sebagai salah satu lembaga pendidikan formal yang bercirikan Islam yang memiliki kurikulum khas, mempunyai tujuan utama mengembangkan potensi anak usia dini dengan dilandasi oleh nilai-nilai ajarannya agama islam dengan visi mewujudkan dan meningkatkan mutu TK Islam Kemaraya Kendari untuk terciptanya generasi yang saleh, berakhlak mulia, cerdas dan kreatif yang selalu mempunyai konstribusi yang positif bagi lingkungan disekitarnya.

Pelaksanaan penelitian tindakan kelas ini dilaksanakan dalam 2 (dua) siklus. Setiap siklus terdiri dari empat kali pertemuan, dilaksanakan sesuai prosedur penelitian. Pelaksanaan tindakan siklus I pertemuan I menggunakan tema diri sendiri dan subtema kepala dengan tema spesifik yaitu rambut, mata dan hidung. Pada pelaksanaan tindakan ini, peneliti melaksanakan skenario pembelajaran yaitu sebelum kegiatan pembelajaran dimulai, didahului dengan apel/berbaris yang dipimpin oleh salah satu anak didik. saat berbaris, setelah barisan anak didik rapi, anak didik menyanyikan beberapa lagu, kemudian mengucapkan salam dan masuk kelas secara berurut sambil memberikan uang tabungannya kepada guru dan mencium tangan ibu guru. Selanjutnya, setelah anak didik telah duduk dengan rapi, anak didik mengucapkan syair, surah Al-Fatihah dan doa sebelum belajar, setelah itu guru mengadakan tanya jawab mengenai rambut mata dan hidung. Pada kegiatan akhir, guru melakukan tanya jawab tentang kegiatan yang telah dilaksanakan. Guru bertanya kepada setiap anak tentang huruf yang tercantum papan tulis, setelah itu menyanyikan beberapa lagu dan mengucapkan doa pulang. Guru mengadakan refleksi kembali pada pembelajaran mengenal huruf hijaiyah.

Siklus I pertemuan II menggunakan tema diri sendiri dan subtema kepala dengan tema spesifik yaitu telinga, mulut, dan gigi. Pada pelaksanaan tindakan ini, peneliti melaksanakan skenario pembelajaran yaitu sebelum kegiatan pembelajaran dimulai, didahului dengan apel/berbaris yang dipimpin oleh salah satu anak didik. Pada saat berbaris, setelah barisan anak didik rapi, anak didik menyanyikan beberapa lagu, kemudian mengucapkan salam dan masuk kelas secara berurut sambil memberikan uang tabungannya kepada guru dan mencium tangan ibu guru. Selanjutnya, setelah anak didik telah duduk dengan rapi, anak didik mengucapkan syair, surah Al-Fatihah dan doa sebelum belajar, setelah itu guru mengadakan tanya jawab mengenai telinga, mulut dan gigi. Pada kegiatan akhir, guru melakukan tanya jawab tentang kegiatan yang telah dilaksanakan. Guru bertanya kepada setiap anak tentang huruf yang tercantum pada media, setelah itu menyanyikan beberapa lagu dan mengucapkan doa pulang. Guru mengadakan refleksi kembali pada pembelajaran mengenal huruf hijaiyah.

Siklus I pertemuan III menggunakan tema diri sendiri dan subtema kepala dengan tema spesifik yaitu telapak, lengan dan kuku. Pada pelaksanaan tindakan ini, peneliti melaksanakan skenario pembelajaran yaitu sebelum kegiatan pembelajaran dimulai, didahului dengan apel/berbaris yang dipimpin oleh salah satu anak didik. Pada saat berbaris, setelah barisan anak didik rapi, anak didik menyanyikan beberapa lagu, kemudian mengucapkan salam dan masuk kelas secara berurut sambil memberikan uang tabungannya kepada guru dan mencium tangan ibu guru. Selanjutnya, setelah anak didik telah duduk dengan rapi, anak didik mengucapkan syair, surah Al-Fatihah dan doa sebelum belajar, setelah itu guru mengadakan tanya jawab mengenai telapak, lengan dan kuku. Pada kegiatan akhir, guru melakukan tanya jawab tentang kegiatan yang telah dilaksanakan. Guru bertanya kepada setiap anak tentang huruf yang tercantum pada media, setelah itu menyanyikan beberapa lagu dan mengucapkan doa pulang. Guru mengadakan refleksi kembali pada pembelajaran mengenal huruf hijaiyah

Siklus I pertemuan IV menggunakan tema diri sendiri dan subtema kepala dengan tema spesifik yaitu jari, siku dan ketiak. Pada pelaksanaan tindakan ini, peneliti melaksanakan skenario pembelajaran yaitu sebelum kegiatan pembelajaran dimulai, didahului dengan apel/berbaris yang dipimpin oleh salah satu anak didik. Pada saat berbaris, setelah barisan anak didik rapi, anak didik menyanyikan beberapa lagu, kemudian mengucapkan salam dan masuk kelas secara berurut sambil memberikan uang tabungannya kepada guru dan mencium tangan ibu guru. Selanjutnya, setelah anak didik telah duduk dengan rapi, anak didik mengucapkan syair, surah Al-Fatihah dan doa sebelum belajar, setelah itu guru mengadakan tanya jawab mengenai jari, siku dan ketiak. Pada kegiatan akhir, guru melakukan tanya jawab tentang kegiatan yang telah dilaksanakan. Guru bertanya kepada setiap anak tentang huruf hijaiyah yang telah di jelaskan, setelah itu menyanyikan 
beberapa lagu dan mengucapkan doa pulang. Guru mengadakan refleksi kembali pada pembelajaran mengenal huruf hijaiyah.

Berdasarkan hasil refleksi terhadap aktivitas guru pada siklus I menunjukkan bahwa proses pembelajaran mengenal huruf hijaiyah dengan menerapkan metode drill masih terdapat kekurangan-kekurangan yang harus diperbaiki. Ini terlihat dari hasil observasi yang dilakukan oleh observer terhadap guru (peneliti) yang menunjukkan adanya hal-hal yang belum sepenuhnya terlaksana yaitu; $23.8 \%$ atau 5 aspek, yang meliputi; a) Guru tidak menciptakan suasana yang hangat dalam belajar, b) guru tidak memotivasi anak untuk rajin belajar, c) guru tidak menuliskan huruf hijaiyahdipapan tulis, d) guru tidak memberi penghargaan kepada anak didik, e) guru tidak memberikan kesimpulan dan pesan-pesan kepada anak didik dan yang tercapai adalah $76.2 \%$ atau 16 aspek dari 21 aspek yang diamati yaitu; a) guru membimbing anak berbaris di depan kelas, b) guru mempersilahkan anak didik masuk kelas, c) guru melakukan persiapan pembelajaran d) guru mengucapkan salam, e) guru membimbing anak untuk berdoa sebelum belajar, f) guru menyampaikan tujuan pembelajaran, g) guru menyiapkan media belajar, h) guru mempersiapkan anak untuk belajar, i) guru menyampaikan lafadz huruf hijaiyah kepada anak didik, j) guru memimpin membaca huruf hijaiyah kepada anak didik sambil menunjukan hurufnya., k) guru meminta anak untuk menyebutkan huruf hijaiyah, 1) guru memberi kesempatan pada anak didik untuk tampil di depan kelas membacakannya (huruf hijaiyah), m) guru memberi penghargaan kepada anak didik. n) guru membimbing anak untuk berdoa sebelum dan sesudah makan, o) guru mengadakan tanya jawab tentang kegiatan yang telah dilaksanakan, dan p) guru membimbing anak untuk berdoa sebelum pulang.

Berdasrkan hasil refleksi pada lembar observasi tersebut maka guru/peneliti melakukan perbaikan pembelajaran pada siklus II dengan memperbaiki kekurangan-kekurangan pada siklus I. Pelaksanaan tindakan siklus II pertemuan I menggunakan tema diri sendiri dan sub tema badan dengan tema spesifik yaitu bahu, dada dan punggung. Pada pelaksanaan tindakan ini, peneliti melaksanakan skenario pembelajaran yaitu sebelum kegiatan pembelajaran dimulai, didahului dengan apel/berbaris yang dipimpin oleh salah satu anak didik. Pada saat berbaris, setelah barisan anak didik rapi, anak didik menyanyikan beberapa lagu, kemudian mengucapkan salam dan masuk kelas secara berurut sambil memberikan uang tabungannya kepada guru dan mencium tangan ibu guru. Selanjutnya, setelah anak didik telah duduk dengan rapi, anak didik mengucapkan syair, surah Al-Fatihah dan doa sebelum belajar, setelah itu guru mengadakan tanya jawab mengenai bahu, dada dan punggung. Pada kegiatan akhir, guru melakukan Tanya jawab tentang kegiatan yang telah dilaksanakan. Guru bertanya kepada setiap anak tentang huruf yang tercantum pada media, setelah itu menyanyikan beberapa lagu dan mengucapkan doa pulang. Guru mengadakan refleksi kembali pada pembelajaran mengenal huruf hijaiyah.

Siklus II pertemuan II dengan menggunakan tema diri sendiri dan sub tema badan dengan tema spesifik yaitu perut, dan pinggang. Pada pelaksanaan tindakan ini, peneliti melaksanakan skenario pembelajaran yaitu sebelum kegiatan pembelajaran dimulai, didahului dengan apel/berbaris yang dipimpin oleh salah satu anak didik. Pada kegiatan akhir, guru melakukan tanya jawab tentang kegiatan yang telah dilaksanakan. Guru bertanya kepada setiap anak tentang huruf yang tercantum pada media, setelah itu menyanyikan beberapa lagu dan mengucapkan doa pulang. Guru mengadakan refleksi kembali pada pembelajaran mengenal huruf hijaiyah.

Siklus II pertemuan III menggunakan tema diri sendiri dan sub tema kaki dengan tema spesifik yaitu paha, lutut dan betis. Pada pelaksanaan tindakan ini, peneliti melaksanakan skenario pembelajaran yaitu sebelum kegiatan pembelajaran dimulai, didahului dengan apel/berbaris yang dipimpin oleh salah satu anak didik. Pada saat berbaris, setelah barisan anak didik rapi, anak didik menyanyikan beberapa lagu, kemudian mengucapkan salam dan masuk kelas secara berurut sambil memberikan uang tabungannya kepada guru dan mencium tangan ibu guru. Selanjutnya, setelah anak didik telah duduk dengan rapi, anak didik mengucapkan syair, surah Al-Fatihah dan doa sebelum belajar, setelah itu guru mengadakan tanya jawab mengenai paha, lutut dan betis. Pada kegiatan akhir, guru melakukan tanya jawab tentang kegiatan yang telah dilaksanakan. Guru bertanya kepada setiap anak tentang huruf yang tercantum pada media, setelah itu menyanyikan beberapa lagu dan mengucapkan doa pulang. 
Guru mengadakan refleksi kembali pada pembelajaran mengenal huruf hijaiyah.

Siklus II pertemuan IV menggunakan tema diri sendiri dan sub tema kaki dengan tema spesifik yaitu mata kaki, tumit dan jari kaki/ kuku. Pada kegiatan akhir, guru melakukan tanya jawab tentang kegiatan yang telah dilaksanakan. Guru bertanya kepada setiap anak tentang huruf yang tercantum pada media, setelah itu menyanyikan beberapa lagu dan mengucapkan doa pulang. Guru mengadakan refleksi kembali pada pembelajaran mengenal huruf hijaiyah.

Pada siklus II guru/peneliti telah melakukan perbaikan, sehingga hasil aktivitas mengajar guru berdasarkan lembar observasi mengalami peningkatan menjadi $90.4 \% 19$ dari 21 aspek yang diamati yaitu : a) Guru membimbing anak berbaris di depan kelas, b) Guru mempersilahkan anak didik masuk kelas, c) Guru melakukan persiapan pembelajaran d) Guru mengucapkan salam, e) Guru membimbing anak untuk berdoa sebelum belajar, f) Guru menyampaikan tujuan pembelajarang) Guru menyiapkan media belajar h). Sedangkan aspek yang diamati yang tidak terlaksanakan berdasarkan pedoman/lembar observasi yaitu $9.6 \%$ atau 2 aspek yang meliputi; a) Gurutidak memantau anak dengan berkeliling dalam kelas dan memberi bimbingan kepada anak dan b) Guru tidak memberikan kesimpulan dan tidak memberikan pesan-pesan.

Hasil observasi aktivitas belajar anak pada siklus I berdasarkan lembar observasi yang akan dicapai oleh guru/peneliti mencapai $80 \%$ atau 12 aspek dari 15 aspek yaitu : a) anak mengikuti apel/ berbaris didepan kelas dengan tertib, b) anak memasuki kelas dengan tertib, c) anak menjawab salam, d) berdoa sebelun belajar dan memimpin doa, e) anak mempersiapkan diri untuk belajar, f) anak dapat memperhatikan guru, g) anak menulis huruf hijaiyah yang ada di papan tulis, h) anak mampu melafadzkan huruf hijaiyah, i) anak dapat berdoa sebelum dan sesudah makan, j). Sedangkan aspek yang diamati yang tidak tercapai adalah sebanyak 3 aspek atau 20\% yang meliputi : a) Anak tidak berani mengemukakan pendapat sendiri, b) Anak tidak membacakan huruf hijaiyah secara bergiliran, dan c) Anak tidak mengajak temannya belajar kelompok.

Pada siklus II berdasarkan lembar observasi, aktivitas belajar anak meningkat menjadi $90.4 \%$ atau 14 aspek dari 15 aspek yaitu : a) anak mengikuti apel/ berbaris didepan kelas dengan tertib, b) anak memasuki kelas dengan tertib, c) anak menjawab salam, d) berdoa sebelun belajar dan memimpin doa, e) anak mempersiapkan diri untuk belajar, f) anak dapat memperhatikan guru, g) anak menulis huruf hijaiyah yang ada di papan tulis, h) anak mampu melafadzkan huruf hijaiyah, i). Sedangkan aspek yang diamati yang tidak tercapai adalah sebanyak 1 aspek atau $6.7 \%$ yaitu anak tidak berani mengemukakan pendapat sendiri.

Hasil evaluasi kemampuan mengenal huruf hijaiyah pada siklus I dengan menerapkan metode drill secara klasikal mencapai tingkat keberhasilan sebesar $47.3 \%$ yang dicapai oleh 9 orang anak didik. Dimana 4 orang anak didik memperoleh nilai bintang $(* * * *)$ atau Berkembang Sangat Baik (BSB) dengan persentase $21.0 \%$ dan 5 orang anak memperoleh nilai bintang $(* * *)$ atau Berkembang Sesuai Harapan (BSH) dengan persentase 26.3\%, namun belum mencapai indikator kinerja yang telah ditentukan yaitu $\geq 75 \%$.

Hasil evaluasi kemampuan mengenal huruf hijaiyah anak pada siklus II dengan menerapkan metode drill secara klasikal mencapai tingkat keberhasilan sebesar 89,4\% yang dicapai oleh 17 orang anak didik. Dimana 7 orang anak didik memperoleh nilai bintang $(* * * *)$ atau Berkembang Sangat Baik (BSB) dengan persentase $36,8 \%$ dan 9 orang anak memperoleh nilai bintang $(* * *)$ atau Berkembang Sesuai Harapan (BSH) dengan persentase $47.3 \%$, telah mencapai indikator kinerja yang telah ditentukan yaitu $\geq 75 \%$.

Hasill penelitian ini sejalan dengan pernyataan Sudjana (1991: 86) metode drill adalah satu kegiatan melakukan hal yang sama, berulang- ulang secara sungguh-sungguh dengan tujuan untuk menyempurnakan suatu keterampilan agar menjadipermanen. Hal ini karena penerapan metode drill sebagai sumber belajar dapat memberikan kesempatan pada anak didik untuk mendapatkan pengetahuan dan memfasilitasi anak untuk menyalurkan keingintahuannya yang kuat. Secara empiris penelitian ini didukung juga penelitian yang dilakukan dilakukan oleh Susilowati (2010), dan Aryani (2014), dimana penerapan metode drill memiliki pengaruh yang signifikan terhadap peningkatan prestasi belajar anak dalam proses pembelajaran.

\section{KESIMPULAN DAN SARAN}

Simpulan dari penelitian ini yaitu ketercapaian aktivitas mengajar guru dalam 
menerapkan metode drillpada pembelajaran mengenal huruf hijaiyah pada siklus I adalah $76.2 \%$ dan pada siklus II adalah 90.4\%. Ketercapaian aktivitas belajar anak dalam menerapan metode drillpada pembelajaran mengenal huruf hijaiyah pada siklus I adalah 80\% dan pada siklus II adalah $93.3 \%$.

Hasil evaluasi kemampuan mengenal huruf hijaiyah anak pada siklus I adalah $47.3 \%$ atau 8 orang dari 19 orang anak, pada siklus II adalah $84.2 \%$ atau 16 orang dari 19 orang anak.

Saran yang dapat dikemukakan dari hasil penelitian ini adalah guru dapat menerapakan metode driil pada tema-tema lainnya sesuai dengan karakteristik tema dan bagi lembagalembaga TK lainnya dapat menggunakan metode driil sebagai alternatif metode pembelajaran untuk mengembangkan kemampuan kognitif anak. .

\section{DAFTAR PUSTAKA}

Anonim. 2014. Modul PLPG 2014 - Penelitian Tindakan Kelas: Rayon 126 Universitas Halu Oleo. Kendari: Universitas Halu Oleo.

Aryani, Rahayu . 2014. Peningkatan Kemampuan Mengenal Huruf Hijaiyah Melalui Bermain Kartu Huruf Pada Siswa. Semarang: Universitas Negeri Semarang.

Darajat, Zakiyah. 1986. Ilmu Pendidikan Islam. Jakarta : Bumi Aksara.

Sudjana, Nana. 1991. Dasar Dasar Proses Belajar Mengajar. Bandung: Sinar Baru.

Sugiyanto. 1996. Metode Drill Menurut Para Ahli, [Online]. Tersedia: http://adhegora.blogspot.com/21/04/201 2/metode-drill-menurut-para-ahli.html [24 april 2015].

Susanto, Ahmad. 2011. Perkembangan Anak Usia Dini. Jakarta: Kencana Prenada Media Group.

Susilowati, Septi. 2010. Upaya meningkatkan kemampuan membaca huruf Hijaiyah dengan metode drill siswa RA An- Nahl: Kalikabong Kalimanah Purbalingga
Zuhairini, dkk. 1995. Filsafat Pendidikan Islam. Jakarta: Bumi Aksara. 